\section{Communication networks and the transnational spread of ethnic conflict}

Nils B Weidmann

Department of Politics and Public Administration, University of Konstanz
Journal of Peace Research

2015, Vol. 52(3) 285-296

(C) The Author(s) 2015

Reprints and permission:

sagepub.co.uk/journalsPermissions.nav DOI: $10.1177 / 0022343314554670$ jpr.sagepub.com

๑SAGE

\begin{abstract}
Theories of conflict diffusion have long argued that domestic conflict spreads from one country to others. One set of mechanisms explaining this relies on material flows across borders that incite violence in neighboring countries. Another set of mechanisms, however, relies on informational flows. Information about ongoing violence elsewhere triggers strategic learning and demonstration effects in subnational conflict actors which may increase the likelihood that these actors ultimately resort to violence. While the first set of mechanisms can be - and has been - assessed using spatial proximity to define connections between countries, this article provides a test of the second mechanism by analyzing communication flows. The article shows that the occurrence of ethnic conflict in a country's main communication partners significantly increases the probability of domestic ethnic violence, and that this effect operates in conjunction with, and is at least as strong as, the spatial contagion effect of conflict in the geographic neighborhood.
\end{abstract}

\title{
Keywords
}

communication, conflict diffusion, ethnic conflict

\section{Introduction}

The emergence of ethnic conflict is often attributed to domestic factors, such as political exclusion, or a low level of economic development. While unquestionably important, this perspective ignores the possibility for transnational mechanisms to impact the risk of political violence. In an era of globalization and an increased international linkage of domestic affairs, these mechanisms have become more and more important. 'What happens abroad affects what happens at home' has become a truism that applies to a variety of political phenomena. This article applies this thinking to ethnic conflict between groups, and studies how it diffuses internationally.

Ethnic conflict can spread internationally in different ways: by direct contagion (i.e. the flow of people and resources across borders), but also through the exchange of information, leading to demonstration effects and strategic learning. The former link is often proxied by geography - transborder flows are typically highest between geographic neighbors. This is why research has focused overwhelmingly on this link, not least because it can be observed more directly and is thus more amenable to empirical analysis. The global exchange of information, however, is largely independent of geography. In our times, information spreads quickly by means of communication technology, such as broadcast media (radio and TV) and peer-to-peer communication channels such as telephone networks. If information accounts for conflict diffusion, these technologies should play a key role.

Can informational links created by communication technology account for the spread of ethnic conflict across borders? This article shows that they do. By analyzing international links as measured by international phone calls between countries, the analysis demonstrates that a tight interaction between countries explains international diffusion. In particular, I find that ongoing ethnic conflict in a state's communication partners increases the risk of ethnic conflict at home. These informational linkages seem to be operating in parallel with geographic linkages. They constitute different types of transnational effects, but these are similar in magnitude and explanatory power. In addition, they are not mere reflections

Corresponding author:

nils.weidmann@uni-konstanz.de 
of more conventional international exchanges (such as, for example, trade or migration). Thus, international communication networks supplement - but do not replace - geography and add an additional layer of interdependence to the international system.

This analysis is relevant as it constitutes one of the first empirical tests of information linkages and their role in promoting conflict diffusion. Through the introduction of a fine-grained, dyadic measure of communication density (international phone calls), I am able to approximate these 'soft' flows of information as opposed to 'hard' flows of resources and people. The strong effect I find for international phone calls attests to the importance of communication as a strong factor affecting the risk of violence. Arguably, the analysis provided can say little as regards the precise mechanisms that account for this effect: absent any information on the sender, the receiver, and the content of a communication, we can only speculate about the actors involved and how international communication affects their decisionmaking. Nevertheless, it can speak to the questions of how different communication technologies can have widely divergent effects on conflict. While earlier work has found centralized communication through news media to be dampening the risk of civil conflict (Warren, 2014), this article demonstrates the opposite for peer-to-peer communication, in line with other cross-national work (Pierskalla \& Hollenbach, 2013; Warren, 2015).

The article first reviews the literature on transnational influences on ethnic conflict, distinguishing between resource- and information-driven mechanisms of diffusion. It then argues that telecommunication patterns between countries can serve as one way to capture this informational flow at the international level; if they do, we should expect the domestic occurrence of conflict to depend partly on the conflict experience of countries it frequently interacts with. The next section introduces the network data used for testing this hypothesis and illustrates the differences between a geographic and a telecommunications network. The last section employs regression analysis with spatially lagged dependent variables to gauge the impact of ethnic conflict in the geographic neighbors as compared with conflict in the communication partners, and shows that both simultaneously increase the risk of conflict onset.

\section{Ethnic conflict and its transnational diffusion}

Research on civil war, and on ethnic conflict in particular, has long focused on the domestic determinants of violence. Whether emphasizing political exclusion at the national level (Wimmer, Cederman \& Min, 2009), weak states (Fearon \& Laitin, 2003) or commitment problems (Fearon, 2004), scholars have taken the state as their point of departure. From there, two developments have been taking place in the last couple of years. The first, and most prominent, was an increased focus on subnational actors and dynamics. In an attempt to disaggregate the study of domestic conflict, scholars have increased the analytical resolution through new data collections and empirical techniques (Cederman \& Gleditsch, 2009). The second is characterized by increased attention to transnational processes that explain (ethnic) civil war (Checkel, 2013). This strand of literature tries to identify international mechanisms affecting the risk of domestic conflict, demonstrating that while civil war and ethnic conflict may be national phenomena, they are subject to a variety of influences originating in other countries. Therefore, we have to factor in the international level when explaining domestic conflict.

When talking about transnational effects on domestic conflict, we need to distinguish between two types: the first comprises mere transnational influences, where a particular process originating in another country affects domestic conflict, without the originating country necessarily experiencing conflict itself. The second comprises diffusion processes in the narrow sense (Elkins \& Simmons, 2005). In a diffusion process, the occurrence of conflict abroad increases the likelihood of violence at home. In other words, conflict in the originating country is necessary to speak of diffusion, in contrast to the first type of mechanism where it is not. Much research on transnational mechanisms has mostly focused on the former. Looking at civil war more generally, Gleditsch (2007) analyzes a number of transnational effects on the domestic risk of violence. Distinguishing between transnational ethnic, political, and economic linkages between a state and its neighbors, he finds that while the former increase a country's risk of civil war, the latter two indicate a tighter integration of a state with its neighbors and thus have negative effect on the conflict risk. Salehyan (2007) highlights the crucial role of transborder sanctuaries for rebel groups to escape government prosecution and rearm. While these examples focus on a state and its direct neighbors, others include transnational effect beyond the direct neighborhood. Salehyan \& Gleditsch (2006) study the effect of refugee inflows and show that the presence of refugees significantly increases the risk of conflict. In the context of ethnic conflict, the presence of transnational ethnic groups is often associated with a higher conflict risk (Weiner, 1971). Here, it is argued that an ethnic kin group across the border can provide 
an incentive for its domestic brethren to secede, and can even support their violent struggle with resources or direct intervention. This has been shown empirically by Cederman, Girardin \& Gleditsch (2009) and Cederman et al. (2013).

The second type of transnational effects, diffusion processes, are the focus of this article. A diffusion process is one where a particular phenomenon travels across a set of entities by direct contagion. As we have seen above, conflict in the originating country is necessary for a diffusion process in the narrow sense. At the same time, however, the joint occurrence of conflict in two neighboring countries is not sufficient for a diffusion process to operate, as parallel developments in the two countries could have led to this outcome, without a direct effect of one conflict on the other (Lake \& Rothchild, 1998; Elkins \& Simmons, 2005; Buhaug \& Gleditsch, 2008). The core focus of research on conflict diffusion has been to find out which transnational mechanisms can lead to diffusion. A useful categorization of these processes focuses on what actually crosses the border between two countries. Here, we can distinguish between (i) resource and demographic flows, on the one hand, and (ii) informational flows, on the other (Lake $\&$ Rothchild, 1998).

Conflict can spread between two countries as a result of the influx of fighters and weapons. This is the most direct type of contagion and applies to all civil wars, not only those of an ethnic nature. These spillover effects can provide existing groups with personnel, skills, and equipment to fuel existing efforts to use violence. Bakke's (2013) case study of the Chechen insurgency illustrates this mechanism. She shows how the presence of 'transnational insurgents' - militants from abroad fighting for a greater Islamist cause - allowed domestic insurgents to benefit from the manpower and skills these people brought in. Another form of spillover may occur through demographic changes that are triggered by another conflict nearby (Lake \& Rothchild, 1998; Salehyan \& Gleditsch, 2006). This mechanism is especially important in the context of ethnic conflict. If an ethnic war triggers population movements of a targeted ethnic group, the immigration of group members can trigger new clashes in the receiving country. Lake \& Rothchild (1998) mention the example of the Democratic Republic of the Congo, which experienced a large influx of Tutsi refugees due to the ongoing conflict in neighboring Rwanda. These refugees led to a violent escalation of ethnic tensions in Eastern Congo. Similarly, ethnic refugees can alter the population distribution to the extent that there are changes in the balance of political power between groups, which can trigger escalation at the center. Whatever the diffusion mechanisms of this category, they are likely to operate primarily within the geographic proximity of a state. That is, the contagion effect of conflict is likely to affect countries in the proximity of the originating state, due to the limited reach of material and demographic flows across borders.

Informational flows constitute the second type of diffusion mechanism. The core assumption is that information about the outbreak and dynamics of ongoing violence reaches actors abroad and leads them to update their beliefs about political claims and government responses, the tactical choices they should make, and the likely outcomes they can achieve (Lake \& Rothchild, 1998). In particular, information about ongoing political violence elsewhere can affect ethnic politics in a country in three ways. First, it can affect the political salience of ethnic boundaries and the political claims groups make based on ethnicity. Kuran (1998) describes a model of the international spread of ethnic identification from one country to another. He argues that under normal conditions, ethnic boundaries often have little political significance and are of little relevance in everyday life. However, induced by the observation of 'ethnic behavior' elsewhere, the population changes toward a state of increased ethnic activity, which can bring ethnic antagonisms to light that had been irrelevant before. Second, learning about ongoing ethnic conflicts can provide potential ethnic challengers with tactical information. Drawing on the social movements literature (Tilly, 1978; Tarrow, 1988), Hill, Rothchild \& Cameron (1998) analyze the diffusion of ethnic protest across countries. In her case study on Chechnya, Bakke (2013) also points to tactical learning and innovation introduced by foreign fighters. Third, observing the success of other ethnic groups in reaching their political goals, groups can alter their beliefs about their own likelihood of success and as a result, increase their demands. Forsberg (2008) shows that this mechanism can trigger domestic conflict, in particular if the information on events abroad falls on fertile ground for conflict.

How exactly does this influx of information lead to conflict? In the following, I distinguish between information exchange according to the actors involved in a conflict mobilization process. Following Kaufman (1996), violent conflict can erupt, broadly speaking, by an elite-led or a mass-led escalation pattern. In the former, political entrepreneurs carefully manipulate public opinion and orchestrate conflict for political gains. By 'ethnically outbidding' their political competitors, they rally the masses behind them, but risk violent conflict. This 
top-down mobilization process is also reflected in several other theories on conflict mobilization, such as the work of de Figueiredo \& Weingast (1999). In top-down mobilization, elites may benefit from an elite-to-elite information exchange across national boundaries. As previous work argues (Hill, Rothchild \& Cameron, 1998), information about particular elite tactics can be a valuable resource and can inspire elites elsewhere to employ similar steps. In short, based on the experience of leaders abroad, domestic ethnic elites can choose to employ mobilization and violence along ethnic lines to further their goals.

The second mobilization pattern, 'bottom-up', works in the opposite direction. Here, aggrieved masses pressure their leaders to push for more group privileges and, ultimately, political violence (Kaufman, 1996). Again, information about ethnic conflict elsewhere can affect the masses, leading to masses-to-masses contagion process, but in two ways. The first informational mechanism relies again on tactical learning and imitation by group members, as described in Hill, Rothchild \& Cameron (1998). With their ethnic brethren abroad using violence to improve the status of their group, domestic groups may feel inclined to do the same. However, in the case of the masses, informational exchange can also lead to a second mechanism, the establishment of shared grievances. If closely related groups in other countries use violence because of political or social discrimination, domestic groups may evaluate and perceive their own situation in a different light. As Cederman, Gleditsch \& Buhaug (2013: 40) argue, inequalities can lead to collective action only if they are jointly perceived as unjust by the group. Communication with peers abroad contributes to this by extending people's frame of reference, that is, by making them aware of their situation through comparison with others abroad. The resulting perception of group-level disadvantages and discrimination together with the belief that political violence may be a feasible way out contributes to the international spread of ethnic violence.

Of course, these mechanisms will all work in conjunction and are difficult to disentangle empirically. However, in contrast to the above-mentioned diffusion by means of people and resources, informational mechanisms of diffusion are not closely limited to the geographic neighborhood of a country, as information can, at least in principle, spread globally. Communication technology provides the means for information to be distributed across national borders. There are two basic modes of transmission: broadcast media such as radio and TV that from one point of origin can reach millions of people, and peer-to-peer communication such as telephones that allow pairs of individuals to communicate. With the global availability of broadcast media, reporting about ethnic conflict abroad should be available almost anywhere, creating (at least the possibility of) information-driven diffusion between almost any pair of states. In addition, studying patterns of television and radio density at the national level, as previous work has done (see for example Warren, 2014), offers little help in finding out about the informational links between two countries, as we do not know about the consumption of broadcasts from the respective country.

Therefore, peer-to-peer communication may provide us with a much more fine-grained picture of information flows between pairs of countries. Peer-to-peer communication consists of interpersonal transmissions between individuals, where typically the sender and receiver know each other relatively well. Information shared between them will be much more personalized and credible than information disseminated through official media channels. In addition, this type of communication is much less prone to state censorship and media bias, such that the exchanged information will appear much more convincing to the people involved. Peer-to-peer communication flows differ widely across pairs of countries, thus offering an opportunity to study whether diffusion of conflict between two countries is more likely if interpersonal interaction via communication is strong. In particular, a state's communication partners, that is, those countries that it shares most interpersonal interactions with, should be those where conflict contagion is most likely to happen. Therefore, the main hypothesis resulting from this discussion is that:

Ethnic conflict in a state's communication partner increases the domestic risk of ethnic violence.

\section{Empirical approach and data}

How can we determine whether ethnic conflict in a state's communication partners affects the domestic risk of violence? This article uses regression analysis on a global sample of data to find out. Essentially, the research design assesses the relative weight of the conventional type of geographic diffusion to an information-based one that follows international communication channels. Earlier research on the spatial dependence of conflict typically relies on 'spatial lag' models, where conflict in the geographic neighbors (however defined) is included as an independent variable. This spatial lag variable can be computed based on different definitions of what 


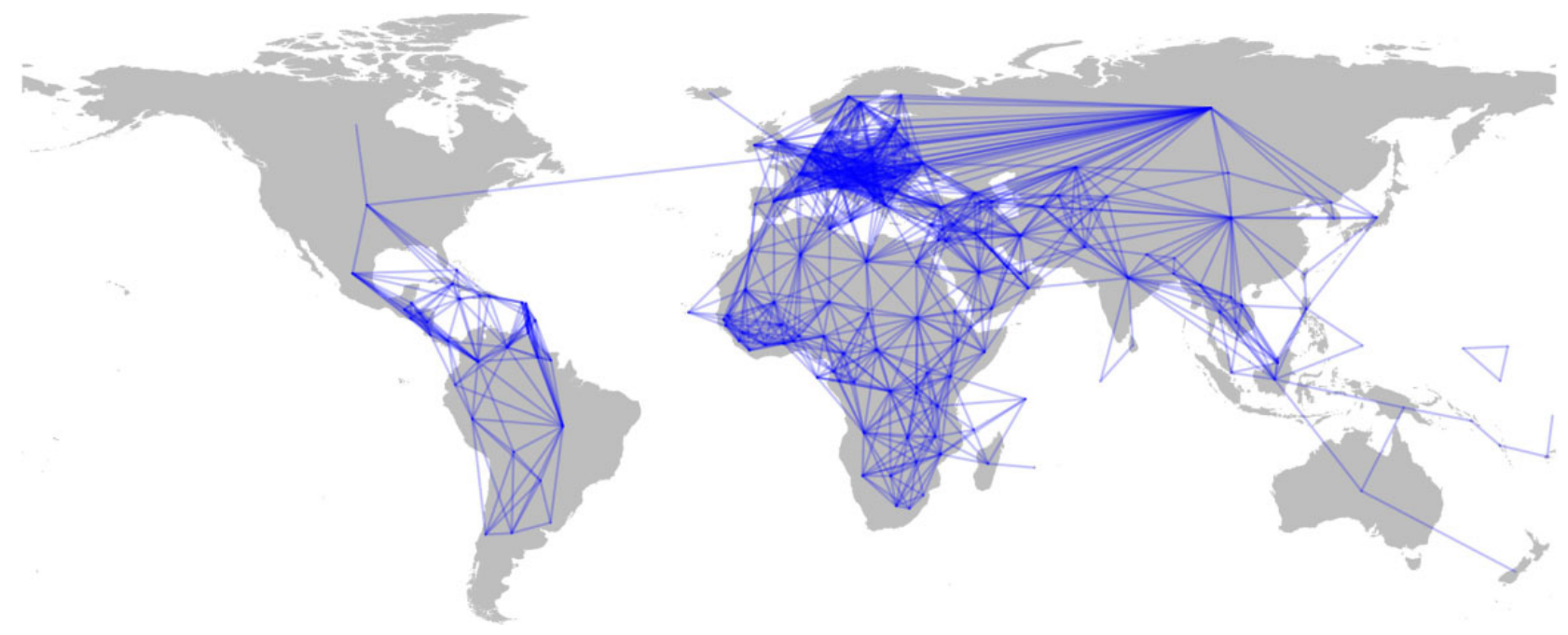

Figure 1. Network of geographic neighbors

constitutes this neighborhood. Earlier work has typically worked with a fixed distance threshold for neighborhood, $950 \mathrm{~km}$ (Gleditsch, 2002). In other words, only those states that are located at a maximum of $950 \mathrm{~km}$ from a given state would be considered neighbors, and the spatial lag would take a value of 1 if one or more of these states are experiencing conflict in the year of observation. ${ }^{1}$

The theoretical discussion above, however, has suggested that geography may not be the only determinant of transnational conflict diffusion. Whereas geography creates opportunities that benefit interaction, other types of global interaction may emerge as a result of choice, that is, the conscious selection of interaction partners abroad. How can we determine the strength of these transnational ties between countries? Telecommunication flows between countries seem to be an ideal way to capture the cultural exchange between two populations, which should ultimately benefit the diffusion of motives and strategy between countries. Telecommunication flows are essentially peer-to-peer connections between citizens in one country to those in another country, made possible through the use of conventional telephony technology or cell phones. If the density of connections from one to another country is high, this indicates that there are many and frequent citizen-to-citizen interactions between the two countries, which facilitates the spread of ideas and information.

\footnotetext{
${ }^{1}$ See Zuhkov \& Stuart (2013) for alternative specifications of distance matrices.
}

The communication density between states over time is taken from the Global Interaction Dataset (Schnorf \& Lazer, 2010), a comprehensive database on dyadic links between countries. Most importantly, the dataset contains dyadic telecommunications flows for the 12-year period from 1996 to 2007, measured in minutes per year. This variable relies on information from the International Telecommunications Union (ITU) and Telegeography, a telecommunications consulting firm. The variable includes all communications via the regular (landline) phone network and the cell phone network by receiving country, but excludes Internet-based phone traffic such as Skype. ${ }^{2}$ The data were collected by relying on statistics from the respective country's regulatory agencies and may thus be prone to certain issues. One of these issues is that the vast majority of countries report only the top ten countries in outgoing traffic. This, however, is not as much of a problem as we may think; after the first ten countries, the percentage of traffic of the following countries decreases sharply and is usually very low (less than $5 \%$ or below). Thus, by looking at the top ten countries, we can safely select out those that are the most frequent communication partners of a country, where the transnational exchange of information is high.

Figures 1 and 2 show visualizations of the geographic and the communication network for the year 2007. The geographic network (Figure 1) is created by linking a country to all neighbors that are at most $950 \mathrm{~km}$ away,

\footnotetext{
${ }^{2}$ Internet-based communication is really picking up only the last couple of years of the study period, so this is not a major issue.
} 


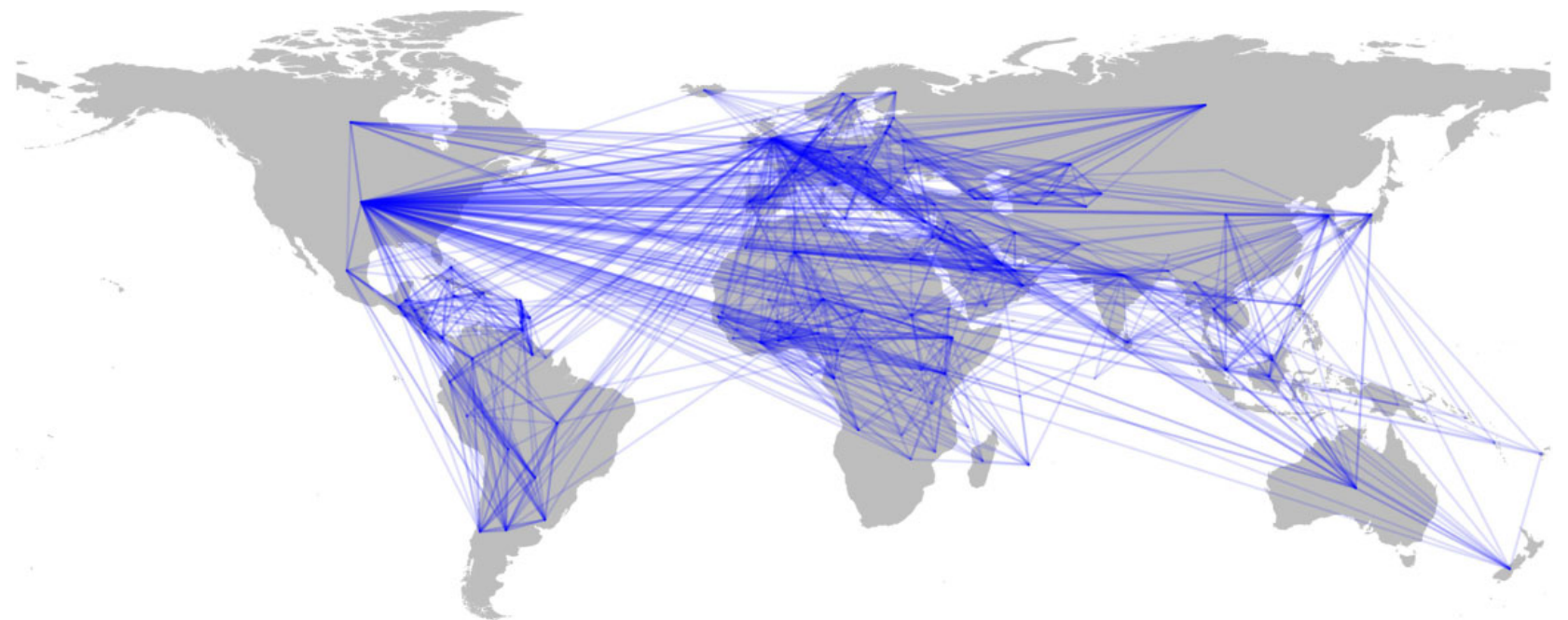

Figure 2. Network of communication partners in 2007

based on the minimum distance between borders obtained from the CShapes dataset (Weidmann, Kuse \& Gleditsch, 2010). The communication network connects a country to the ten other countries that received most of its international phone calls (Figure 2). Not surprisingly, the global communication network is very different from a network based on spatial proximity. By construction, the latter features short links only, whereas the telecommunication network has a large number of long-distance links, connecting for example countries such as South Korea and the USA. ${ }^{3}$ Also, both networks have a number of 'hubs', that is, countries with a high number of connections. However, these hubs are different in the two networks. In the geographic network, Russia is one of these hubs because of the large number of states in its proximity. The same applies to a number of small European states, which have a number of neighbors around them. The USA, however, has few geographic neighbors and does not have a eminent position in the network. In the communications network, the picture is very different. Russia is clearly not a hub here in contrast to the USA, which maintains links with a large number of countries.

\section{Results}

This section presents regression results using spatially lagged conflict incidence as the main independent

\footnotetext{
${ }^{3}$ The long link between Russia and the USA in the spatial network is due to the map projection that artificially separates both countries.
}

variable. The spatial lags are computed using the different networks introduced above, geographic and communication (cf. Beck, Gleditsch \& Beardsley, 2006), and are lagged one year. The spatial lags indicate whether at least one geographic neighbor (according to the geographic network) or communication partner (according to the communication network) experienced an ongoing ethnic conflict in the year before. The onset and incidence of ethnic conflict is taken from the GROWup data portal (http://growup.ethz.ch). ${ }^{4}$ In line with earlier literature that highlights political exclusion as a key driver of ethnic conflict (Cederman, Wimmer \& Min, 2010), I control for the proportion of excluded population. ${ }^{5}$ In addition, the models include the usual control variables employed in regression analysis of ethnic conflict: GDP per capita and the country population based on the Penn World Tables (Heston, Summers \& Aten, 2006), and a democracy indicator from the Polity IV dataset (Marshall \& Jaggers, 2008), taking a value of 1 if the combined polity score is 6 or higher. Due to the limited availability of the communication flow data, all regressions are limited to the period 1996-2007 and to 162 countries, reducing the number of observations to 1,726 . In order to control for serial correlation, I employ the approach proposed by Carter \& Signorino (2010) and include the number of

${ }^{4}$ This conflict coding is based on different data sources: Wucherpfenning et al. (2012), Cederman, Wimmer \& Min (2010), Cunningham, Gleditsch \& Salehyan (2009), and Gleditsch et al. (2002).

${ }^{5}$ Other indicators that capture the same give similar results, for example the Nstar indicator (Cederman \& Girardin, 2007). 
Table I. Logit regression results

Dependent variable:

Ethnic conflict onset

\begin{tabular}{lrrrr} 
& (1) & (2) & \multicolumn{1}{c}{ (3) } & \multicolumn{1}{c}{ (4) } \\
\cline { 2 - 5 } Conflict in geographic neighbor $(t-1)$ & & $1.471^{*}(0.735)$ & & $1.247^{\dagger}(0.740)$ \\
Conflict in communication partner $(t-1)$ & & & $1.089^{* *}(0.416)$ & $0.936^{*}(0.431)$ \\
Excluded population & $0.442(0.869)$ & $0.408(0.852)$ & $0.677(0.836)$ & $0.605(0.822)$ \\
GDP per capita $(\log )$ & $-0.071(0.193)$ & $-0.033(0.183)$ & $-0.175(0.187)$ & $-0.138(0.185)$ \\
Population (log) & $0.336^{\dagger}(0.179)$ & $0.287^{\dagger}(0.163)$ & $0.214(0.164)$ & $0.189(0.152)$ \\
Democracy & $-0.372(0.489)$ & $-0.132(0.493)$ & $-0.121(0.501)$ & $0.044(0.498)$ \\
Constant & $-6.053^{* *}(2.208)$ & $-7.263^{* *}(2.205)$ & $-4.643^{*}(2.124)$ & $-5.775^{* *}(2.147)$ \\
Observations & 1,726 & 1,726 & 1,726 & 1,726 \\
\hline
\end{tabular}

$\dagger_{p}<0.1 ;{ }^{*} p<0.05 ;{ }^{* *} p<0.01$. Dependent variable: onset of ethnic conflict. Standard errors clustered by country. Peace-years controls not shown.

peace-years (as well as in squared in cubic transformations). Robust standard errors are clustered by country. Table I reports the results. ${ }^{6}$

Model 1 is the base model that includes only the controls. All variables receive their expected signs, but most fail to reach conventional levels of significance: the size of the excluded population is positively related to conflict, and richer countries have a lower risk of conflict. The likelihood of conflict onset is higher in larger countries, but lower in democracies. In Model 2, I add the spatial lag of ethnic conflict, according to the geographic network. This variable receives a positive and significant coefficient, supporting earlier findings about conflict diffusion between proximate countries. The effect is strong; keeping all controls at their means (and the democracy dummy at 0 ), a country with ethnic conflict in its neighborhood has a predicted probability of conflict onset of 0.013 as compared with 0.004 for a country without. Model 3 adds the spatial lag based on the communication network instead. Again, we observe a positive and significant effect. Comparing again a country with and without conflict in its communication partners, the predicted probability drops from 0.019 to 0.007 . If, despite the graphical illustration above, we are still worried that the geographic and communication network overlap to a large extent, this is not confirmed by the data: the two spatial lags correlate only at 0.193 , which is why they can be safely tested in a joint model. Model 4 includes both spatial lags, and confirms their independent effects.

\footnotetext{
${ }^{6}$ All results computed using the $\mathrm{R}$ statistical toolkit and the logit.gee model (Lam, 2014) from the Zelig (Imai, King \& Lau, 2008) package. Tables created using stargazer (Hlavac, 2013).
}

Individually, conflict in a geographic neighbor or conflict in a communication partner roughly triples the predicted risk of conflict (from 0.003 to 0.008 , in both cases). A country with conflict both in its geographic neighbor and in one of its communication partners has almost a sevenfold risk of conflict as compared with one with neither (from 0.003 to 0.021 ). Thus, at least according to these first results, ethnic conflict spreads independently through both geographic proximity and transnational communication links.

However, we may be worried that communication networks are only reflections of other types of transnational linkages. In order to test for this, Models 5 and 6 in Table II test the effect of lagged ethnic conflict based on the communication network against other types of networks.

Model 5 includes as independent variables both the dummy for conflict in communication partners as defined above, and a similar variable based on the trade network. The latter is created by linking a country to its ten most important trade partners based on bilateral trade volume. While the corresponding coefficient is positive, it fails to reach significance by far. Model 6 repeats this using a migration network. Here, a country is linked to those countries from which it received most immigration. Again, this variable fails to display a significant effect, and the importance of communicationinduced diffusion remains. As a final test, I assess whether non-ethnic conflict is similarly prone to information-based diffusion as ethnic conflict above. To this end, Model 7 regresses the onset of non-ethnic civil war on its spatial lag (based on the communication network). The non-ethnic conflicts are typically opportunity-driven rebellions by small subgroups of the 
Table II. Additional logit regression results

\begin{tabular}{|c|c|c|}
\hline \multicolumn{2}{|c|}{ Ethnic conflict onset } & \multirow{2}{*}{$\frac{\text { Non-ethnic conflict onset }}{\text { (7) }}$} \\
\hline (5) & (6) & \\
\hline \multirow{2}{*}{$\begin{array}{r}1.054^{*}(0.427) \\
0.183(0.433)\end{array}$} & $1.137^{*}(0.463)$ & \\
\hline & $-0.337(0.682)$ & \\
\hline $0.637(0.839)$ & $0.642(0.823)$ & $0.858(1.207)$ \\
\hline$-0.149(0.193)$ & $-0.162(0.195)$ & $-0.469^{*}(0.204)$ \\
\hline $0.225(0.158)$ & $0.226(0.167)$ & $0.302^{\dagger}(0.158)$ \\
\hline$-0.147(0.495)$ & $-0.136(0.507)$ & $-0.381(0.447)$ \\
\hline$-5.038^{*}(2.182)$ & $-4.590^{*}(2.093)$ & $-3.098^{\dagger}(1.745)$ \\
\hline 1,726 & 1,726 & 1,726 \\
\hline
\end{tabular}

Conflict in communication partner $(t-1)$

Conflict in trade partner $(t-1)$

Conflict in migration partner $(t-1)$

Non-ethnic conflict in communication partner $(t-1)$

Excluded population

GDP per capita (log)

Population (log)

Democracy

Constant

Observations
Dependent variable:

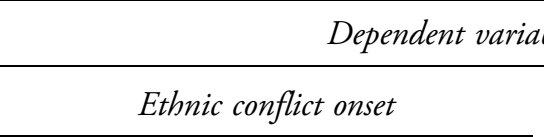

(6) (1)

$\dagger_{p}<<0.1 ;{ }^{*} p<0.05 ;{ }^{* *} p<0.01$. Dependent variable: onset of ethnic conflict. Standard errors clustered by country. Peace-years controls not shown.

population. In contrast to ethnic civil wars that result from broader societal grievances, violence in these nonethnic conflicts does not occur for a broader public cause (Sambanis, 2001). The absence of a positive effect of the lagged dependent variable may suggest that this type of conflict is less susceptible to communication-induced mobilization, since we require neither elite-driven nor mass-driven information exchange for it to happen. Due to the low number of conflict cases entering this result, however, it has to be treated with caution.

\section{Assessing bias from unobservables}

The regressions above control for a number of observable factors that potentially affect the relationship between conflict in communication partners and conflict at home. However, as in most observational studies, it may still be the case that the presence of unobservable variables contributes to the correlation we observe, leading us to falsely conclude a causal impact of conflict abroad on domestic ethnic conflict. In order to assess the likelihood that these unobservable variables account for the positive relationship, we can apply a procedure presented by Altonji, Elder $\&$ Taber (2005). ${ }^{7}$ The aim of this procedure is to assess how much stronger, in comparison to observed control variables, the unobserved factors would have to be before the effect of the key independent

\footnotetext{
7 The Altonji, Elder and Taber procedure was subsequently adapted for linear regressions by Bellows \& Miguel (2009) and is used in Nunn \& Wantchekon (2011). The result from this procedure is based on a linear probability model, which was also used in the present study.
}

variable goes away. We can get an estimation of this magnitude by comparing the coefficient $\hat{\beta}^{F}$ of the main independent variable - the communication-lagged conflict indicator - in an unrestricted (full) model with all controls with the difference in coefficients between the restricted model (with only temporal controls, coefficient estimate $\hat{\beta}^{R}$ ) and the full model. Specifically, I report the ratio $\hat{\beta}^{F} /\left(\hat{\beta}^{R}-\hat{\beta}^{F}\right)$; the denominator of this term is the attenuation of the effect introduced by the observables (the controls in the unrestricted model). If the ratio of the numerator (the effect estimated in the full model) remains large in comparison to the attenuation introduced by observed controls, (hypothetical) selection on unobservables would have to be strong in order to decrease the effect to zero. Therefore, higher values of this ratio make it unlikely that unobserved confounders drive the relationship. ${ }^{8}$ Table III reports the results for the effect of the communication-lagged conflict variables, based on Models 3 and 4 from Table I.

As we can see in Table III, the ratios are well above 1, both in Model 3 and Model 4. For comparison, Nunn \& Wantchekon (2011) consider ratios of 3 and above to be unproblematic. For the analysis, this means that the transnational effect on conflict brought about by

\footnotetext{
${ }^{8}$ This presupposes of course that the controls introduced in the full model are known to be strong predictors of conflict, otherwise their marginal change in the coefficient would be small, leading to a large ratio. In the present application, many of the controls introduced (excluded population, GDP, and population) are known to be strong predictors of civil war.
} 
Table III. Assessment of potential bias from unobservables

Controls in the restricted set $R$ Controls in the full set $F$ Ratio

Peace-years

Full set from Model $3 \quad 13.93$

Peace-years

Full set from Model $4 \quad 16.16$

Method used to assess potential bias from unobservables is from Altonji, Elder \& Taber (2005). The reported values are the ratio $\hat{\beta}^{F} /\left(\hat{\beta}^{F}-\hat{\beta}^{R}\right)$.

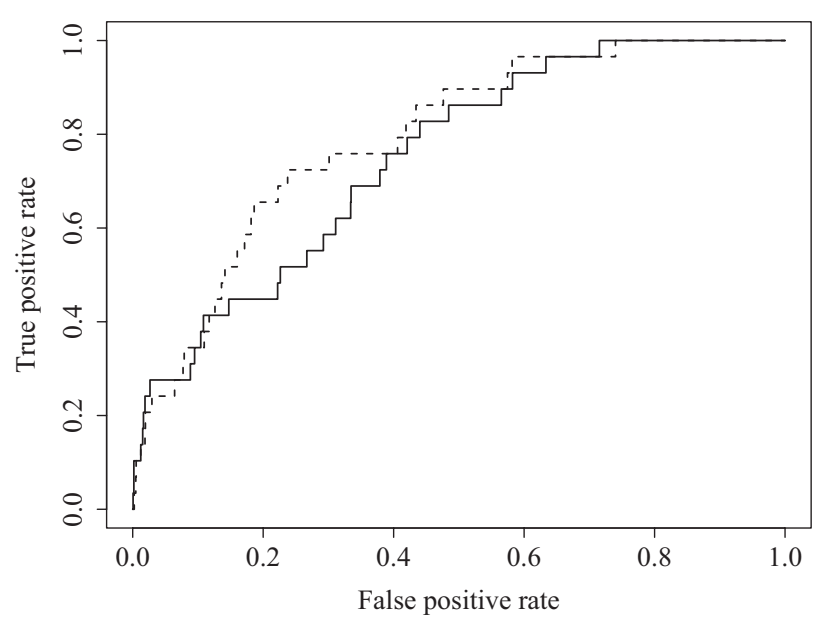

Figure 3. ROC curve comparing the base model (Model 1 in Table I, solid line) to Model 3 (dashed line)

communication networks is unlikely to be caused by unobserved confounders that are not controlled for in the models reported above.

\section{Predictive impact}

The above results demonstrate the statistical effect of communication-induced conflict diffusion. However, can conflict in a communication partner also improve our predictions of violence? As Ward, Greenhill \& Bakke (2010) argue, there has been (too) much emphasis on statistical significance in quantitative work on conflict. In order to make the models more relevant, an alternative assessment is to analyze the predictive power of the model. When using a binary model as done in the analysis above, this amounts to finding out how many cases are correctly classified by the model. However, since from the model we typically only get a predicted probability of conflict for each case rather than a binary classification, the state-of-the-art method for analyzing these models is by means of Receiver Operating Characteristic (ROC) analysis. The basic idea of ROC analysis is to vary the probability threshold for positive prediction among all cases, and to determine the true positive and the false positive rate for each threshold. This results in a so-called ROC curve, where models that predict well end up in the top left corner (high rate of true positives, low rate of false positives). Figure 3 plots these ROC curves for the base model (Model 1) and Model 3, which adds only the communication-lagged conflict variable. Thus, the difference between the two curves is due to the inclusion of this variable and can be used as an estimate of its predictive impact.

The increase in predictive accuracy when including conflict in communication partners in the models is clearly visible in Figure 3, where the dashed line is almost always above the solid line. Thus, compared to Model 1, Model 3 is almost always able to achieve a higher rate of true positives and a lower rate of false positives in a prediction task. In addition, we can specify the predictive quality of the models by measuring the 'area under the curve' (AUC), which has a maximum value of 1 . For the base model, the AUC is 0.751 . When added the spatial lag in Model 2, the AUC goes up to 0.779 . Adding only the conflict in communication partner variable in Model 3 , the AUC further increases to 0.792 , indicating that the conflict diffusion in the communication network even surpasses geography in a prediction task. Together, the two variables improve the AUC to 0.804 in Model 4.

\section{Conclusion}

It is often argued that the emergence of modern communication technology will lead to the death of distance, or in other words, the shrinking importance of geography to determine global interaction (Cairncross, 2001). At least for international wars, this assumption does not seem to hold true (Buhaug \& Gleditsch, 2006). Still, in the context of domestic conflict, the story may be slightly more complex. While the above analysis has shown that the exchange of information via communication networks matters for the transnational diffusion of ethnic conflict, this does not mean that geography becomes irrelevant. On the contrary, spatial proximity facilitates diffusion to the same extent as 'social' proximity measured by communication exchanges. Hence, the increasing interconnectedness of global affairs that is introduced by modern technology adds a new layer of interstate linkage, but does not replace old layers.

The results of this analysis add several new insights for our understanding of ethnic conflict. First, they attest to the importance of information-driven diffusion mechanisms, which have received little empirical analysis so far. Due to the possibility of observing non-material transnational interactions, the analysis of bilateral telecommunication 
interactions offers a novel way to study transnational effects. In the information age where the speed and scope of peer-to-peer communication is increasing to higher and higher levels, the relative impact of these diffusion channels is likely to grow. Second, the results could be interpreted as empirical support for the importance of bottom-up, mass-driven mobilization for ethnic conflict. The communication exchanges used for this analysis capture broad, society-level interactions between the masses of two countries, rather than elite-driven, highlevel exchanges. The finding that these interactions matter for the spread of ethnic conflict could be evidence in favor of society-level grievances as drivers of ethnic violence (Cederman, Weidmann \& Gleditsch, 2011). At the same time, however, this does not rule out the possibility that elite-to-elite communication accounts for international conflict diffusion, as argued in other work (Danneman \& Ritter, 2014; Nome \& Weidmann, 2013) - it is simply that the telecommunication data employed here is not able to pick this up. Further work will be needed to reconcile these opposing findings.

Even though this analysis constitutes one more step towards a better understanding of communication technology and politics, further empirical work will be able to shed more light on the mechanisms at work. In particular, the availability of communication data at the national level but not below - severely limits the extent to which we can understand the processes at work. With better communication data, for example at the level of groups, we could understand if really the exchange between the aggrieved masses of two countries is responsible for the transnational diffusion of conflict. One way to push this research agenda is by resorting to geo-referenced data on network access, as other work is doing (Bailard, 2015). This would allow for the creation of group-level measures of communication, which could then be combined with flow data at the international level. Further work and innovations in social science data collection and processing may pave the way for more nuanced analyses on this question.

\section{Replication data}

The dataset and $\mathrm{R}$ code for the empirical analysis in this article can be found at http://www.prio.no/jpr/datasets.

\section{Acknowledgements}

The author gratefully acknowledges permission from David Lazer and Sebastian Schnorf to use their Global Interaction Dataset for this project.

\section{Funding}

This research is supported by the Alexander von Humboldt Foundation (Sofja Kovalevskaja Award).

\section{References}

Altonji, Joseph G; Todd E Elder \& Christopher R Taber (2005) Selection on observed and unobserved variables: Assessing the effectiveness of Catholic schools. Journal of Political Economy 113(1): 151-184.

Bailard, Catie Snow (2015) Ethnic conflict goes mobile: Mobile technology's effect on the opportunities and motivations for violent collective action. Journal of Peace Research 52(3): 323-337.

Bakke, Kristin M (2013) Copying and learning from outsiders? Assessing diffusion from transnational insurgents in the Chechen wars. In: Jeffrey T Checkel (ed.) Transnational Dynamics of Civil War. New York: Cambridge University Press, 31-62.

Beck, Nathaniel; Kristian Skrede Gleditsch \& Kyle Beardsley (2006) Space is more than geography: Using spatial econometrics in the study of political economy. International Studies Quarterly 50(1): 27-44.

Bellows, John \& Edward Miguel (2009) War and local collective action in Sierra Leone. Journal of Public Economics 93(11): 1144-1157.

Buhaug, Halvard \& Kristian Skrede Gleditsch (2008) Contagion or confusion? Why conflicts cluster in space. International Studies Quarterly 52: 215-233.

Buhaug, Halvard \& Nils Petter Gleditsch (2006) The death of distance? The globalization of armed conflict. In: Miles Kahler \& Barbara Walter (eds) Territoriality and Conflict in an Era of Globalization. Cambridge: Cambridge University Press, 187-216.

Cairncross, Francis (2001) The Death of Distance: How the Communications Revolution Is Changing Our Lives. Cambridge, MA: Harvard Business Press.

Carter, David B \& Curtis S Signorino (2010) Back to the future: Modeling time dependence in binary data. Political Analysis 18(3): 271-292.

Cederman, Lars-Erik \& Kristian Skrede Gleditsch (2009) Introduction to special issue on 'Disaggregating civil war'. Journal of Conflict Resolution 53(4): 487-495.

Cederman, Lars-Erik \& Luc Girardin (2007) Beyond fractionalization: Mapping ethnicity onto nationalist insurgencies. American Political Science Review 101(1): 173-185.

Cederman, Lars-Erik; Luc Girardin \& Kristian Skrede Gleditsch (2009) Ethno-nationalist triads: Assessing the influence of kin groups on civil wars. World Politics 61(3): 403-437.

Cederman, Lars-Erik; Kristian Skrede Gleditsch \& Halvard Buhaug (2013) Inequality, Grievances, and Civil War. New York: Cambridge University Press.

Cederman, Lars-Erik; Kristian Skrede Gleditsch, Idean Salehyan \& Julian Wucherpfennig (2013) Transborder 
ethnic kin and civil war. International Organization 67(2): 389-410.

Cederman, Lars-Erik; Nils B Weidmann \& Kristian Skrede Gleditsch (2011) Horizontal inequalities and ethno-nationalist civil war: A global comparison. American Political Science Review 105(3): 478-495.

Cederman, Lars-Erik; Andreas Wimmer \& Brian Min (2010) Why do ethnic groups rebel? New data and analysis. World Politics 62(1): 87-119.

Checkel, Jeffrey T (2013) Transnational dynamics of civil war. In: Jeffrey T Checkel (ed.) Transnational Dynamics of Civil War. New York: Cambridge University Press, 3-27.

Cunningham, David E; Kristian Skrede Gleditsch \& Idean Salehyan (2009) It takes two: A dyadic analysis of civil war duration and outcome. Journal of Conflict Resolution 53(4): 570-597.

Danneman, Nathan \& Emily H Ritter (2014) Contagious rebellion and preemptive repression. Journal of Conflict Resolution 58(2): 254-279.

de Figueiredo, Rui \& Barry R Weingast (1999) The rationality of fear: Political opportunism and ethnic conflict. In: Barbara F Walter \& Jack Snyder (eds) Civil Wars, Insecurity, and Intervention. New York: Columbia University Press, 261-302.

Elkins, Zachary \& Beth Simmons (2005) On waves, clusters, and diffusion: A conceptual framework. Annals of the American Academy of Political and Social Science 598: 33-51.

Fearon, James D (2004) Why do some civil wars last so much longer than others? Journal of Peace Research 41(3): 275-301.

Fearon, James D \& David D Laitin (2003) Ethnicity, insurgency and civil war. American Political Science Review 97(1): 75-90.

Forsberg, Erika (2008) Polarization and ethnic conflict in a widened strategic setting. Journal of Peace Research 45(2): 283-300.

Gleditsch, Kristian Skrede (2002) All International Politics is Local: The Diffusion of Conflict, Integration and Democratization. Ann Arbor, MI: University of Michigan Press.

Gleditsch, Kristian Skrede (2007) Transnational dimensions of civil war. Journal of Peace Research 44(3): 293-309.

Gleditsch, Nils Petter; Peter Wallensteen, Mikael Eriksson, Margareta Sollenberg \& Håvard Strand (2002) Armed conflict 1946-2001: A new dataset. Journal of Peace Research 39(5): 615-637.

Heston, Alan; Robert Summers \& Bettina Aten (2006). Penn World Tables version 6.2 (https://pwt.sas.upenn.edu/).

Hill, Stuart; Donald Rothchild \& Colin Cameron (1998) Tactical information and the diffusion of peaceful protests. In: David A Lake \& Donald Rothchild (eds) The International Spread of Ethnic Conflict: Fear, Diffusion and Escalation. Princeton, NJ: Princeton University Press, 61-88.

Hlavac, Marek (2013) stargazer: LaTeX code for well-formatted regression and summary statistics tables. $\mathrm{R}$ package, version 3.0.1 (https://sites.google.com/site/ marekhlavac/stargazer).
Imai, Kosuke; Gary King \& Olivia Lau (2008) Toward a common framework for statistical analysis and development. Journal of Computational and Graphical Statistics 17(4): 892-913.

Kaufman, Stuart (1996) Spiraling to ethnic war: Elites, masses and Moscow in Moldova's civil war. International Security 21(2): 108-138.

Kuran, Timur (1998) Ethnic dissimilation and its international diffusion. In: David A Lake \& Donald Rothchild (eds) The International Spread of Ethnic Conflict. Princeton, NJ: Princeton University Press, 35-60.

Lake, David A \& Donald Rothchild (1998) Spreading fear: The genesis of transnational ethnic conflict. In: David A Lake \& Donald Rothchild (eds) The International Spread of Ethnic Conflict. Princeton, NJ: Princeton University Press, 3-34.

Lam, Patrick (2014) logit.gee: Generalized estimating equation for logistic regression. In: Kosuke Imai, Gary King \& Olivia Lau (eds) Zelig: Everyone's Statistical Software, 258-266 (http://r.iq.harvard.edu/docs/zelig.pdf, http:// gking.harvard.edu/zelig).

Marshall, Monty G \& Keith Jaggers (2008). Polity IV project: Political regime characteristics and transitions, 1800-2007 (http://www.systemicpeace.org/polity/polity4.htm).

Nome, Martin \& Nils B Weidmann (2013) Diffusion mechanisms of armed civil conflict: The case of social identities. In: Jeffrey $\mathrm{T}$ Checkel (ed.) Transnational Dynamics of Civil War. New York: Cambridge University Press, 173-203.

Nunn, Nathan \& Leonard Wantchekon (2011) The slave trade and the origins of mistrust in Africa. American Economic Review 101(7): 3221-3252.

Pierskalla, Jan H \& Florian M Hollenbach (2013) Technology and collective action: The effect of cell phone coverage on political violence in Africa. American Political Science Review 107(2): 207-224.

Salehyan, Idean (2007) Transnational rebels: Neighboring states as sanctuary for rebel groups. World Politics 59(2): 217-242.

Salehyan, Idean \& Kristian Skrede Gleditsch (2006) Refugees and the spread of civil war. International Organization 60(2): 335-366.

Sambanis, Nicholas (2001) Do ethnic and nonethnic civil wars have the same causes? A theoretical and empirical inquiry (Part 1). Journal of Conflict Resolution 45(3): 259-282.

Schnorf, Sebastian \& David Lazer (2010) Global Interaction Dataset, version 10. Unpublished dataset. Boston, MA: Northeastern University.

Tarrow, Sidney (1988) National politics and collective action: Recent theory and research in Western Europe and the United States. Annual Review of Sociology 14: 421-440.

Tilly, Charles (1978) From Mobilization to Revolution. Reading, MA: Addison-Wesley. 
Ward, Michael D; Brian D Greenhill \& Kristin M Bakke (2010) The perils of policy by p-value: Predicting civil conflicts. Journal of Peace Research 47(4): 363-375.

Warren, T Camber (2014) Not by the sword alone: Soft power, mass media, and the production of state sovereignty. International Organization 68(1): 111-141.

Warren, T Camber (2015) Explosive connections? Mass media, social media, and the geography of collective violence in African states. Journal of Peace Research 52(3): 297-311.

Weidmann, Nils B; Doreen Kuse \& Kristian Skrede Gleditsch (2010) The geography of the international system: The CShapes dataset. International Interactions 36(1): 86-106.

Weiner, Myron (1971) The Macedonian syndrome: A historical model of international relations and political development. World Politics 23(4): 665-683.

Wimmer, Andreas; Lars-Erik Cederman \& Brian Min (2009) Ethnic politics and armed conflict: A configurational analysis of a new global dataset. American Sociological Review 74(2): 316-337.

Wucherpfennig, Julian; Nils W Metternich, Lars-Erik Cederman \& Kristian Skrede Gleditsch (2012) Ethnicity, the state, and the duration of civil wars. World Politics 64(1): 79-115.

Zhukov, Yuri M \& Brandon M Stuart (2013) Choosing your neighbors: Networks of diffusion in international relations. International Studies Quarterly 57(2): 271-287.

NILS B WEIDMANN, b. 1976, PhD in Political Science (ETH Zurich, 2009); Professor of Political Science,

University of Konstanz, Germany (2012- ) and head of the 'Communication, Networks and Contention' research group; research interests: violent and nonviolent conflict, with a particular focus on the impact of communication and information technology. 